\title{
WHAT CAUSES FLUCTUATIONS IN THE TERMS OF TRADE?
}

\author{
Marianne Baxter \\ Michael A. Kouparitsas \\ Working Paper 7462 \\ http://www.nber.org/papers/w7462
NATIONAL BUREAU OF ECONOMIC RESEARCH
1050 Massachusetts Avenue
Cambridge, MA 02138
January 2000

All errors and omissions are our own. The views expressed herein are those of the authors and not necessarily those of the Federal Reserve Bank of Chicago, the Federal Reserve System, or the National Bureau of Economic Research.

(C) 2000 by Marianne Baxter and Michael A. Kouparitsas. All rights reserved. Short sections of text, not to exceed two paragraphs, may be quoted without explicit permission provided that full credit, including $(\mathbb{C})$ notice, is given to the source. 
What Causes Fluctuations in the Terms of Trade?

Marianne Baxter and Michael A. Kouparitsas

NBER Working Paper No. 7462

January 2000

JEL No. E32, F41

\section{ABSTRACT}

This paper investigates the sources of terms of trade volatility, specifically addressing the relative importance of goods-price effects vs. country-price effects. For fuel exporters, most of the terms of trade variation stems from goods-price effects, as one would have expected, a priori. For commodity exporters, there is great dispersion in the importance of goods price effects vs. country price effects, and no overall generalization is possible. Exporters of manufactured goods face terms of trade variation that appears to be about equally due to goods-price effects and country-price effects. Key words: Terms of trade; International business cycles.

Marianne Baxter

Department of Economics

University of Virginia

Charlottesville, VA 22901

and NBER

mb6s@virginia.edu
Michael A. Kouparitsas

Federal Reserve Bank of Chicago

P.O. Box 834

Chicago, IL 60690

mkoup@frbchi.org 


\section{Introduction}

Fluctuations in the terms of trade-the price of a country's exports relative to the price of its imports-are associated with large variations in national income. While terms of trade shocks and the consequent income fluctuations are larger in developing countries, terms of trade shocks are also important for larger, industrialized countries. This paper investigates the sources of terms of trade volatility.

On the one hand, a country's terms of trade may fluctuate simply because the country exports one basket of goods and imports a different basket of goods. The OPEC nations, for example, export mainly petroleum products yet import a wide range of other goods. It would be natural to expect that fluctuations in the terms of trade for OPEC countries would be dominated by movements in the world price of oil. We will call this effect on the terms of trade a "goods price" effect since it stems from variations in the relative price of two different goods.

On the other hand, however, much recent research has documented the empirical importance of cross-country deviations from the law of one price. Some of this research stresses the importance of pricing-to-market behavior, whereby producers in one country set different prices for their product, depending on the country in which it is sold; see, for example, the work of Knetter (1993) and Goldberg and Knetter (1997). Other research has documented deviations from the law of one price, sometimes using country-wide price indexes, and sometimes using data on fairly narrow classes of goods-see, for example, the work of Engel (1993, 1999), Engel and Rogers (1996), and Rogers and Jenkins (1995). We will call this effect on the terms of trade a "country price" effect since it stems from the fact that the same good sells for different prices in different countries.

Given the empirical evidence, it appears likely that both goods price effects and country price effects are important for understanding terms of trade volatility. The goal of the present paper, then, is to determine the contribution of each of these effects to overall terms of trade volatility. Further, we explore whether a terms of trade decomposition into goods price effects and country price effects is similar across countries.

The paper is structured as follows. Section 2 discusses the data that we use in our subsequent empirical analysis. Section 3 presents information on terms of trade volatility and the structure of exports and imports for the countries in our sample. 
Section 4 discusses issues associated with performing a decomposition of the terms of trade into goods-price and country-price effects. We show that there is not a unique decomposition of this form, and illustrate the structure of the alternative decompositions that we will use. Section 5 contains our empirical results on terms of trade decompositions into goods-price and country-price effects. We discuss similarities and differences across different groups of countries: manufactures-exporters vs. commodity exporters; developed countries vs. developing countries. This section also discusses the implications of our empirical findings for future work in open economy macroeconomics. Section 6 concludes.

\section{Data sources and definitions}

The data are from the World Bank's World Tables (1991). This database contains information on annual merchandise trade data for 100 countries, over the period from 1969 to 1988 (the data were not collected after 1988). These data include export price indices and trade value series for exports and imports of three broad categories of merchandise trade: non-fuel commodities, fuels and manufactured goods. Each of these categories conforms to a Standard International Trade Classification (SITC): non-fuel commodities are the sum of SITC codes $0,1,2,4$, and 68 ; fuels correspond to SITC code 3, and manufactured goods correspond to SITC codes 5, 6, 7, and 8, except for code 68 .

This dataset does not contain price data for individual import good categories. Since most countries import goods from a large number of trade partners ((see, for example, Michaely (1984), chapter 4), we construct a measure of the "rest of the world" price of each good to stand in for the individual country import prices. Specifically, we construct the "rest of the world" price index for good $i$ for country $k$ using a Paasche index:

$$
P_{i k t}^{M} \equiv \frac{\sum_{j \neq k} P_{i j t}^{X} X_{i j t}}{\sum_{j \neq k} P_{i j o}^{X} X_{i j t}},
$$

where, $P_{i j t}^{X}$ is the $j$ th country's $\$$ US export price for the $i$ th good, $X_{i j t}$ is the volume of $i$ th good exported by the $j$ th country at time $t$, and $P_{i j o}^{X}$ is the $j$ th country's base year export price for the $i$ th good. To ensure that constructed import prices for each good are consistent with the actual aggregate import prices, the import price of 
manufactures is computed as a residual. ${ }^{1}$

Since the World Tables do not use a common base year for all countries, we scale the price data so that each series is equal to one in 1986-this becomes the base year that we use in constructing the world price indices. Export and import expenditure shares are sample averages over the period 1969 to 1988. Throughout, we work with growth rates of the price indexes. We do this for two reasons. First, the short-term fluctuations in goods prices, especially commodity and fuel prices, are much larger and presumably more important to policy makers than are the longer-term trends in these prices. Second, the likely presence of unit roots in the price series would make it impossible to perform a simple variance decomposition without the use of some type of filter. We experimented with the Hodrick-Prescott (1997) filter and found our results were very similar to the results for growth rates.

\section{Terms of trade volatility and trade structure}

This section reviews the salient properties of the data on trade structure and terms of trade volatility. Table 1 summarizes the structure of international trade and the volatility of the terms of trade for several groups of countries. For each of the 100 countries in our sample, we computed the export and import shares devoted to each of three classes of goods: commodities, fuels, and manufactures. Table 1 shows that there is great variation across countries in the export shares for each of these three groups, while there is much less variation across countries in the import shares. This table also shows net export shares for each type of good, computed as the export share minus the import share.

Countries are divided into groups according to largest net export share. For example, a country is classified as a "commodity exporter" if the net export share of commodities for that country exceeds the net export shares for fuels and manufactures. We further subdivided the countries into developing and developed countries

\footnotetext{
${ }^{1}$ Specifically,
}

$$
P_{m j t}^{M} \equiv \frac{P_{j t}^{M} M_{j t}-\sum_{i \neq m} P_{i j t}^{M} M_{i j t}}{P_{j o}^{M} M_{j o}-\sum_{i \neq m} P_{i j o}^{M} M_{i j o}},
$$

where, $P_{i j t}^{M}$ is the $j$ th country's constructed $\$$ US import price for the $i$ th good $(i=m=$ manufactures), $P_{j t}^{M}$ is the $j$ th country's aggregate $\$$ US import price, $M_{i j t}$ is the volume of the $i$ th good imported by the $j$ th country, $M_{j t}$ the $j$ th country's aggregate import volume at time $t, P_{i j o}^{M}$ is the $j$ th country's base year import price for the $i$ th good, and $P_{j o}^{M}$ the $j$ th country's base year aggregate import price. 
based on their IMF classification-see Appendix A for a complete list of countries by group.

Looking first at developing countries, we find that most of these (60 of 79) are net exporters of commodities: agricultural products and primary products. All but one of the world's main fuel exporters are also listed with the developing countries, accounting for another 15 of this group. There are only four developing countries that are net exporters of manufactured goods: Hong Kong, Israel, Korea, and Malta.

Most of the developed countries in our sample are net exporters of manufactured goods; of the 21 developed countries, only 8 are commodity exporters (Canada is included in this sub-group), and only Norway is a net fuel exporter.

Table 1 shows that the volatility of terms of trade growth differs greatly across groups of countries. Developing country fuel exporters have the most volatile terms of trade, with a standard deviation of the annual growth rate of the terms of trade equal to nearly $32 \%$ per year. The volatility of the terms of trade for developing country commodity exporters is about $12 \%$ per year, while the terms of trade volatility for developing country manufactured-goods exporters is only about $7 \%$ per year.

The terms of trade volatility for developed countries does not display a similar pattern to the one for developed countries. That is: there is similar volatility for all countries in this group, and there is no apparent tendency for fuel exporters and commodity exporters to have more volatile terms of trade (see Appendix B for detailed results for individual countries). In fact, the manufactured-good exporters have the most volatile terms of trade among developed countries, and the single fuel exporter (Norway) has the least volatile terms of trade. This may be due to the fact that the export bundles of the developed countries are not as specialized as those of the developing countries. For example, developing country commodity exporters have a commodity export share of $67 \%$, compared with a commodity export share of only $43 \%$ for developed country commodity exporters. Developing country fuel exporters have an export share of fuels of $86 \%$, compared with only $28 \%$ for the single fuel exporter in the developed country group. The export shares for manufactured goods are similar for both developing and developed-country manufactured goods exporters.

The bottom panel of Table 1 shows terms of trade volatility and trade structure for several of the major industrialized countries. The 'typical' industrialized country is usually viewed as an exporter of manufactured goods and an importer of commodities and fuels. In this regard, Japan is the country that best fits this characterization, 
with the highest share of net fuel imports of all the countries or groups listed in Table 1. Japan also has the largest export share of manufactured goods of all countries in our sample $(96 \%)$ as well as the largest net export share (71\%).

Several of the other industrialized countries are also 'typical' industrialized countries, with negative net export shares for commodities and fuels, and positive net export shares for manufactured goods. Yet there are two notable exceptions. Canada is a net exporter of commodities, primarily timber products, and is the only net importer of manufactured goods among the major industrialized countries. The US is similar to Canada (and unlike the other major industrialized countries) in being a net exporter of commodities. In fact, the US has similar net export shares of commodities and manufactured goods: $7 \%$ and $8 \%$ of net exports, respectively.

Overall, the data suggest that there is a link between a country's terms of trade volatility and that country's trade structure. However, the dissimilarity between the groups of developing and developed countries suggests that there may also be a role for country-specific influences on the terms of trade. In the remainder of this paper, we provide evidence on the importance of each of these forces in explaining fluctuations in a country's terms of trade.

\section{Measurement}

The goal of this work is to determine how much of a country's terms of trade volatility is due to variation in the relative price of different goods, stemming from the fact that the country exports and imports different baskets of goods. Another force leading to terms of trade variation is that the import price of a particular good is different from the export price of the same good. We are interested in determining the relative importance of each of these factors in explaining the overall volatility of the terms of trade.

\subsection{Conceptual issues: The 2-good case}

To illustrate the issues involved in constructing a terms of trade decomposition, we begin by studying a situation in which there are only two goods: commodities and manufactures. Let $p^{x}$ denote the log of the aggregate export price deflator. Then

$$
p^{x}=\alpha_{c}^{x} p_{c}^{x}+\alpha_{m}^{x} p_{m}^{x}
$$


where $p_{i}^{x}$ is the export price of good $i$, and the subscripts denote the particular export good: $\quad c$ for commodities, and $m$ for manufactured goods. ${ }^{2}$ The share of good $i$ in the export basket is denoted $\alpha_{i}^{x}$, with $\alpha_{c}^{x}+\alpha_{m}^{x}=1$.

The aggregate import deflator, $p^{m}$, is given by:

$$
p^{m}=\alpha_{c}^{m} p_{c}^{m}+\alpha_{m}^{m} p_{m}^{m}
$$

where $\alpha_{i}^{m}$ is the share of good $i$ in the import basket, $p_{i}^{m}$ is the country's import price of good $i$, and where $\alpha_{c}^{m}+\alpha_{m}^{m}=1$.

Subtracting (3) from (2) yields the log terms of trade, $p^{x}-p^{m}$ :

$$
p^{x}-p^{m}=\alpha_{c}^{x} p_{c}^{x}+\alpha_{m}^{x} p_{m}^{x}-\left(\alpha_{c}^{m} p_{c}^{m}+\alpha_{m}^{m} p_{m}^{m}\right) .
$$

Equation (4) is not in a form that will allow us to determine the influence of goods prices vs. country prices on the overall terms of trade. Using the notation just developed, an example of a "goods price" is $\left(p_{c}^{x}-p_{m}^{x}\right)$. These are both export prices (the superscript $x$ ), but export prices of different goods (the subscripts indicating commodities, $c$, and manufactures, $m$ ). By contrast, an example of a "country price" is $\left(p_{m}^{x}-p_{m}^{m}\right)$ because it refers to the same good (the subscript $m$ ) with different prices (the superscript denoting exports vs. imports).

Through algebraic manipulation of (4) we can express the terms of trade as the sum of goods price components and country price components. However, there is not a unique decomposition of this form. To see why, let's think further about the country price components. As noted above, the country price component for manufactures is $\left(p_{m}^{x}-p_{m}^{m}\right)$; for fuels it is $\left(p_{f}^{x}-p_{f}^{m}\right)$ and for commodities, $\left(p_{c}^{x}-p_{c}^{m}\right)$. In order to aggregate these into their effects on the overall terms of trade, it is natural to multiply each good's country price term by the good's share in a particular basket. But should these be the import-basket shares or the export-basket shares? There is no a priori reason to prefer one over the other. Thus there will be two decompositions: one that uses the export shares as the weights for the country price terms, and one that uses the import shares as the weights for the country price terms.

\footnotetext{
${ }^{2}$ In actual practice, aggregate prices are an arithmetic rather than a geometric weighted average of disaggregated prices. We find that aggregate prices constructed with geometric averages have variance/covariance properties that closely approximate those of aggregate prices constructed with arithmetic averages.
} 
Let's go through the details of the decomposition that uses the export weights for the country price terms. Subtracting equation (3) from equation (2) yields the following:

$$
\begin{aligned}
p^{x}-p^{m} & =\alpha_{c}^{x}\left(p_{c}^{x}-p_{c}^{m}\right)+\alpha_{m}^{x}\left(p_{m}^{x}-p_{m}^{m}\right)+\left(\alpha_{c}^{x}-\alpha_{c}^{m}\right) p_{c}^{m}+\left(\alpha_{m}^{x}-\alpha_{m}^{m}\right) p_{m}^{m} \\
& =\alpha_{c}^{x}\left(p_{c}^{x}-p_{c}^{m}\right)+\alpha_{m}^{x}\left(p_{m}^{x}-p_{m}^{m}\right)+\left(\alpha_{c}^{x}-\alpha_{c}^{m}\right) p_{c}^{m}+\left(\left(1-\alpha_{c}^{x}\right)-\left(1-\alpha_{c}^{m}\right)\right) p_{m}^{m} \\
& =\alpha_{c}^{x}\left(p_{c}^{x}-p_{c}^{m}\right)+\alpha_{m}^{x}\left(p_{m}^{x}-p_{m}^{m}\right)+\left(\alpha_{c}^{x}-\alpha_{c}^{m}\right) p_{c}^{m}-\left(\alpha_{c}^{x}-\alpha_{c}^{m}\right) p_{m}^{m} \\
& =\underbrace{\alpha_{c}^{x}\left(p_{c}^{x}-p_{c}^{m}\right)+\alpha_{m}^{x}\left(p_{m}^{x}-p_{m}^{m}\right)}_{\text {country prices }}+\underbrace{\left(\alpha_{c}^{x}-\alpha_{c}^{m}\right)\left(p_{c}^{m}-p_{m}^{m}\right)}_{\text {goods prices }} .
\end{aligned}
$$

In equation (5), the first two terms on the right-hand-side involve "country prices"the relative export and import prices of commodities (the first term) and manufactures (the second term) multiplied by the export shares. The last term in equation (5) is a goods price term, involving the relative import prices of commodities to manufactures.

There is a second decomposition that can be constructed by using the import shares to construct the country price components. Subtracting (3) from (2) once again, but now letting the coefficients on the country price components be import shares, we have:

$$
\begin{aligned}
p^{x}-p^{m} & =\alpha_{c}^{m}\left(p_{c}^{x}-p_{c}^{m}\right)+\alpha_{m}^{m}\left(p_{m}^{x}-p_{m}^{m}\right)+\left(\alpha_{c}^{x}-\alpha_{c}^{m}\right) p_{c}^{x}+\left(\alpha_{m}^{x}-\alpha_{m}^{m}\right) p_{m}^{x} \\
& =\alpha_{c}^{m}\left(p_{c}^{x}-p_{c}^{m}\right)+\alpha_{m}^{m}\left(p_{m}^{x}-p_{m}^{m}\right)+\left(\alpha_{c}^{x}-\alpha_{c}^{m}\right) p_{c}^{x}+\left(\left(1-\alpha_{c}^{x}\right)-\left(1-\alpha_{c}^{m}\right)\right) p_{m}^{x} \\
& =\alpha_{c}^{m}\left(p_{c}^{x}-p_{c}^{m}\right)+\alpha_{m}^{m}\left(p_{m}^{x}-p_{m}^{m}\right)+\left(\alpha_{c}^{x}-\alpha_{c}^{m}\right) p_{c}^{x}-\left(\alpha_{c}^{x}-\alpha_{c}^{m}\right) p_{m}^{x} \\
& =\underbrace{\alpha_{c}^{m}\left(p_{c}^{x}-p_{c}^{m}\right)+\alpha_{m}^{m}\left(p_{m}^{x}-p_{m}^{m}\right)}_{\text {country prices }}+\underbrace{\left(\alpha_{c}^{x}-\alpha_{c}^{m}\right)\left(p_{c}^{x}-p_{m}^{x}\right)}_{\text {goods prices }}
\end{aligned}
$$

As in equation (5), the first two terms are country price components: note that the coefficients are now import shares. The third term is the goods price component, involving the relative export prices of commodities to manufactures. Note that the goods price term now involves relative export prices, whereas the goods price term in (5) involved relative import prices.

The two decompositions, (5) and (6), will give different results for the terms of trade decomposition into goods price components and country price components. These two decompositions reflect different choices of numeraire for the underlying basket of goods against which the country price components are calculated. In the next sections, we present decompositions along these lines when there are three goods instead of two. 


\subsection{Country prices vs. goods prices: The 3-good case}

As before, let $p^{x}$ denote the log of the aggregate export price deflator. Then

$$
p^{x}=\alpha_{c}^{x} p_{c}^{x}+\alpha_{f}^{x} p_{f}^{x}+\alpha_{m}^{x} p_{m}^{x}
$$

where, $\alpha_{i}^{x}$ is the share of good $i$ in the export basket, $p_{i}^{x}$ is export price of good $i$, and the subscripts denote the particular export good: $c$ for commodities, $f$ for fuels, and $m$ for manufactured goods. The shares sum to one: $\alpha_{c}^{x}+\alpha_{f}^{x}+\alpha_{m}^{x}=1$.

The aggregate import deflator, $p^{m}$, is given by:

$$
p^{m}=\alpha_{c}^{m} p_{c}^{m}+\alpha_{f}^{m} p_{f}^{m}+\alpha_{m}^{m} p_{m}^{m}
$$

where $\alpha_{i}^{m}$ is the share of good $i$ in the import basket, $p_{i}^{m}$ is the country's import price of good $i$, and $\alpha_{c}^{m}+\alpha_{f}^{m}+\alpha_{m}^{m}=1$.

Combining (7) and (8) yields the log terms of trade, $p^{x}-p^{m}$ :

$$
p^{x}-p^{m}=\alpha_{c}^{x} p_{c}^{x}+\alpha_{f}^{x} p_{f}^{x}+\alpha_{m}^{x} p_{m}^{x}-\left(\alpha_{c}^{m} p_{c}^{m}+\alpha_{f}^{m} p_{f}^{m}+\alpha_{m}^{m} p_{m}^{m}\right) .
$$

As described in the preceding sub-section, we can work with equation (9) to express the terms of trade as the sum of goods price components and country price components. However, we found that there is not a unique decomposition of this form. In the two-good case, there were 2 such decompositions; in this three-good setting, there are $6 .{ }^{3}$ Fortunately, there are two main classes of decompositions which correspond, as before, to a choice of the basket weights used to compute country price components. One class uses export shares, another class uses import shares. However, there are more choices to be made once there are more than two goods. Within the goods price components, one must choose a specific numeraire good. Since there are 3 goods, this will produce 3 variations within each class of decompositions. Within each class, the three variations will give the same variance decomposition into goods and country price components. The three variations within a particular class differ only in the fraction of variance attributed to particular goods prices. This will become clearer as we work through the details of the decomposition.

\footnotetext{
${ }^{3}$ That is: there are 6 decompositions in which there is a clear separation of "goods price" terms from "country price" terms. If we are willing to permit terms that involve mixtures of goods prices and country prices-a term such as $\left(p_{f}^{x}-p_{c}^{m}\right)$ would be an example-then there are many more potential decompositions of the terms of trade.
} 


\subsection{The first decomposition}

Through appropriate addition and subtraction of terms, equation (9) can be rewritten as follows:

$$
\begin{aligned}
p^{x}-p^{m}= & \underbrace{\left(\alpha_{c}^{x}-\alpha_{c}^{m}\right)\left(p_{c}^{m}-p_{m}^{m}\right)+\left(\alpha_{f}^{x}-\alpha_{f}^{m}\right)\left(p_{f}^{m}-p_{m}^{m}\right)}_{\text {goods prices }} \\
& +\underbrace{\alpha_{c}^{x}\left(p_{c}^{x}-p_{c}^{m}\right)+\alpha_{f}^{x}\left(p_{f}^{x}-p_{f}^{m}\right)+\alpha_{m}^{x}\left(p_{m}^{x}-p_{m}^{m}\right)}_{\text {country prices }} .
\end{aligned}
$$

The first two terms on the right-hand-side of equation (10) are goods prices. The first term is the price of commodity imports relative to manufactured-goods imports; the second term is the price of fuel imports relative to manufactured goods imports. The last three terms are country prices-the export price relative to the import price for each of the three goods (commodities, fuels, manufactures), all weighted by export shares.

There are two other decompositions of the overall terms of trade that are very similar to (10), in the sense that they also use export shares for country prices:

$$
\begin{aligned}
& p^{x}-p^{m}=\underbrace{\left(\alpha_{m}^{x}-\alpha_{m}^{m}\right)\left(p_{m}^{m}-p_{c}^{m}\right)+\left(\alpha_{f}^{x}-\alpha_{f}^{m}\right)\left(p_{f}^{m}-p_{c}^{m}\right)}_{\text {goods prices }} \\
& +\underbrace{\alpha_{c}^{x}\left(p_{c}^{x}-p_{c}^{m}\right)+\alpha_{f}^{x}\left(p_{f}^{x}-p_{f}^{m}\right)+\alpha_{m}^{x}\left(p_{m}^{x}-p_{m}^{m}\right)}_{\text {country prices }} . \\
& p^{x}-p^{m}=\underbrace{\left(\alpha_{c}^{x}-\alpha_{c}^{m}\right)\left(p_{c}^{m}-p_{f}^{m}\right)+\left(\alpha_{m}^{x}-\alpha_{m}^{m}\right)\left(p_{m}^{m}-p_{f}^{m}\right)}_{\text {goods prices }} \\
& +\underbrace{\alpha_{c}^{x}\left(p_{c}^{x}-p_{c}^{m}\right)+\alpha_{f}^{x}\left(p_{f}^{x}-p_{f}^{m}\right)+\alpha_{m}^{x}\left(p_{m}^{x}-p_{m}^{m}\right)}_{\text {country prices }} .
\end{aligned}
$$

Equations (11)-(12) differ from equation (10) only in the goods price terms. Specifically, equation (10) expressed goods prices relative to the import price of manufactures. By contrast, equation (11) expresses goods prices relative to the import price of commodities and equation (12) expresses goods prices relative to the import price of fuels. Because each of the three country price terms is identical across equations (10)-(12), the fraction of variance attributable to each of the country price terms is also identical across the three equations. Further, this means that the terms 
of trade variance attributed to the sum of all goods price effects must be the same across the three equations. The only difference across the three specifications will be in the breakdown for the individual goods price components which, as we have just noted, differ across the three equations.

\subsection{The second decomposition}

There is a second class of decompositions that uses the import basket shares as the basis for computing country price effects. As noted in the preceding sub-section, this leads to different results for the breakdown of the terms of trade into goods price and country price components. As in the prior sub-section, there are three variations within this class-one for each possible specification of the numeraire for the computation of goods prices. In equation (10), the goods price terms were all expressed relative to the (import) price of manufactured goods. In the current class

of decompositions, the goods price terms will involve export prices. If we express goods prices relative to the export price of manufactures, and use the import basket shares for computing country price effects, we obtain the following:

$$
\begin{aligned}
& p^{x}-p^{m}= \underbrace{\left(\alpha_{c}^{x}-\alpha_{c}^{m}\right)\left(p_{c}^{x}-p_{m}^{x}\right)+\left(\alpha_{f}^{x}-\alpha_{f}^{m}\right)\left(p_{f}^{x}-p_{m}^{x}\right)}_{\text {country prices }} \\
&+\underbrace{\alpha_{c}^{m}\left(p_{c}^{x}-p_{c}^{m}\right)+\alpha_{f}^{m}\left(p_{f}^{x}-p_{f}^{m}\right)+\alpha_{m}^{m}\left(p_{m}^{x}-p_{m}^{m}\right)}_{\text {goods prices }} .
\end{aligned}
$$

As before, there are two additional decompositions that yield the same country price/goods price breakdown as that given in (13); these are as follows:

$$
\begin{aligned}
p^{x}-p^{m}= & \underbrace{\left(\alpha_{m}^{x}-\alpha_{m}^{m}\right)\left(p_{m}^{x}-p_{c}^{x}\right)+\left(\alpha_{f}^{x}-\alpha_{f}^{m}\right)\left(p_{f}^{x}-p_{c}^{x}\right)}_{\text {goods prices }} \\
+\underbrace{\alpha_{c}^{m}\left(p_{c}^{x}-p_{c}^{m}\right)+\alpha_{f}^{m}\left(p_{f}^{x}-p_{f}^{m}\right)+\alpha_{m}^{m}\left(p_{m}^{x}-p_{m}^{m}\right)}_{\text {country prices }} & \underbrace{p^{x}-p^{m}=}_{\text {country prices }} \\
& \underbrace{(\alpha_{c}^{x}-\underbrace{\alpha_{c}^{m}\left(p_{c}^{x}-p_{c}^{m}\right)+\alpha_{f}^{m}\left(p_{f}^{x}-p_{f}^{m}\right)+\alpha_{m}^{m}\left(p_{m}^{x}-p_{m}^{m}\right)}_{c} .\left(\alpha_{m}^{x}-\alpha_{m}^{m}\right)\left(p_{m}^{x}-p_{f}^{x}\right)}_{\text {goods prices }} .
\end{aligned}
$$


The next section puts these decompositions to work.

\section{Explaining variation in the terms of trade}

The preceding section developed expressions that relate the overall terms of trade to goods price components and country price components. This exercise did not yield a unique breakdown of the terms of trade along these lines. Thus our empirical implementation of these results should be viewed as providing upper and lower bounds on the goods price/country price decomposition of terms-of-trade volatility.

\subsection{Volatility of goods prices and country prices}

Before looking at the variance decomposition based on equation (10), it is useful to get an idea of the volatility of the goods price and country price components. Table 2 shows the volatility of terms of trade growth as well as each of the possible goods price and country price terms.

There are several key facts that are evident from Table 2. First, the volatility of goods prices (the relative price of different export goods or different import goods) exceeds the volatility of the overall terms of trade by a substantial amount. The relative prices that involve fuels are particularly volatile. Second, country prices (export prices of particular goods, relative to import prices) are much less volatile than goods prices, and also tend to be less volatile than the overall terms of trade except for the country price for fuels.

\subsection{Goods prices vs. country prices: A first look}

This sub-section discusses results based on one particular decomposition of the terms of trade, equation (10), reproduced below:

$p^{x}-p^{m}=\left(\alpha_{c}^{x}-\alpha_{c}^{m}\right)\left(p_{c}^{m}-p_{m}^{m}\right)+\left(\alpha_{f}^{x}-\alpha_{f}^{m}\right)\left(p_{f}^{m}-p_{m}^{m}\right)+\alpha_{c}^{x}\left(p_{c}^{x}-p_{c}^{m}\right)+\alpha_{f}^{x}\left(p_{f}^{x}-p_{f}^{m}\right)+\alpha_{m}^{x}\left(p_{m}^{x}-p_{m}^{m}\right)$

The variance of the terms of trade computed from this equation will have five variance terms (one for each term on the right-hand-side) plus 10 covariance terms. The covariance between term $i$ and term $j$ is apportioned equally between terms 
$i$ and $j .{ }^{4}$ When the covariance between two terms is negative, there is thus the potential for the overall contribution to terms-of-trade variance of a particular term to be negative. This tends to happen when the direct contribution to variance of a term is quite small. In practice, there are only a few small, negative entries in the tables. ${ }^{5}$

The results for the variance decomposition based on this equation are presented in Table 3. This table shows the fraction of terms of trade variability due to goods price components and country price components, together with a breakdown within each category. As in Table 1, results are presented in summary form for groups of countries; the detailed results for each country can be found in Appendix B.

To understand the structure of the table, it is helpful to look at one case in detail. The first entry is for developing country commodity exporters; the statistics shown are export-value-weighted means within the group. Within this group of countries, then, the decomposition shown in equation (10) attributes $41 \%$ of terms of trade variation to movements in relative goods prices (column 2), with the remaining $59 \%$ due to movements in relative country prices (column 3).

The other columns of Table 3 show a more detailed breakdown within each groupcolumns 4 and 5 have the details on goods price components, while columns 6-8 contain details on the country price components. Continuing to look at developingcountry commodity exporters, we find that movements in the relative import price of commodities to manufactures (column 4) accounts for $27 \%$ of overall terms of trade volatility, while movements in the import price of fuels relative to manufactures (column 5) accounts for 14\%. The country price sub-components are in columns 6-8. Variation in the relative country prices of commodities (column 6) accounts for $42 \%$ of overall terms of trade volatility, while variation in relative country prices of fuels and manufactures (columns 7 and 8 ) account for $0 \%$ and $16 \%$, respectively.

Let's step back from the details and try to see whether there are any broad inferences that can be drawn from Table 3. For developing countries as a group, more of the terms of trade variation is due to goods prices compared with country prices ( $52 \%$ goods price effects, vs. $48 \%$ country price effects), while the reverse is true for developed countries ( $42 \%$ due to goods prices, $58 \%$ due to country prices).

\footnotetext{
${ }^{4}$ Rogers and Jenkins (1995) also handled the covariance terms this way, in their decompositions of the variance of real exchange rates.

${ }^{5}$ The covariance terms typically explain between $10 \%$ and $20 \%$ of the variance of the overall terms of trade-omitting the covariance terms altogether would not change the main results of the paper.
} 
This result is partly due to the fact that developed countries mainly export fuels and commodities, while developed countries are mainly manufactures exporters. Fuel exporters in both groups show a much larger share of terms of trade variation coming from goods price components relative to country price components. By contrast, terms of trade volatility for commodities exporters and manufactures exporters in both groups is mainly due to country price effects.

The lower panel of Table 3 contains disaggregated results for the major industrialized countries. For most of these countries, the results show a roughly equal split between goods price components and country price components. For Canada and the UK, however, the country price component is much larger than the goods price component. The major contribution to the goods price component is typically the import price of fuels relative to manufactures. The most important country price component is the export price of manufactures relative to the import price, all multiplied by the export share of manufactures (this share is large in all of these countries, except Canada). If we were to draw a rough generalization from Table 3, we would say that terms of trade variation is about equally due to goods price variation and country price variation, except for fuel exporters. For these countries, goods price effects account for about three-fourths of overall terms of trade variation.

\subsection{The alternative decomposition}

Table 4 shows the variance decomposition of the terms of trade for the alternative specification:

$p^{x}-p^{m}=\left(\alpha_{c}^{x}-\alpha_{c}^{m}\right)\left(p_{c}^{x}-p_{m}^{x}\right)+\left(\alpha_{f}^{x}-\alpha_{f}^{m}\right)\left(p_{f}^{x}-p_{m}^{x}\right)+\alpha_{c}^{m}\left(p_{c}^{x}-p_{c}^{m}\right)+\alpha_{f}^{m}\left(p_{f}^{x}-p_{f}^{m}\right)+\alpha_{m}^{m}\left(p_{m}^{x}-p_{m}^{m}\right)$.

One main difference between this specification and equation (10) studied earlier is that the coefficients on the country price terms are now import shares, whereas these coefficients were export shares in equation (10). Further, the goods price components in the equation above are relative export prices, whereas the goods price components were relative import prices in the decomposition presented in Table 3.

The results for this alternative decomposition are presented in Table 4 . For developing country commodity exporters, the goods price component is the largest source of terms of trade variation-this stands in contrast to the results shown in Table 
3 , where the country price component was dominant. The results are also reversed for developing country exporters of manufactures: the country price effect is much smaller $(59 \%)$ than it was in Table $3(87 \%)$.

The breakdown for developing-country fuel exporters is similar across Tables 3 and 4, with the predominant effect coming from goods prices. In contrast to the results for developing countries, which were sensitive to the specific decomposition employed, the results for the three groups of developed countries shown in Table 4 are very similar to the results from Table 3. Specifically, goods price effects dominate for fuel exporters, while country price effects are most important for exporters of manufactures.

The summary statistics for the three groups of countries at the world level suggest that there is little difference in the variance decompositions across the two specifications: commodity exporters and manufactured-good exporters have terms of trade variation driven by country effects, while fuel exporters' terms of trade are driven by relative price changes. Yet these aggregates mask the fact that the two decompositions can give very different answers for specific countries.

The lower panel of Table 4, in parallel with Table 3, shows results for several of the industrialized countries. The results are largely similar across Tables 3 and 4 for Canada, Germany and Italy. For the other countries-France, Japan, the UK, and the US-the Table 4 specification leads to differences in the goods price/country price decompositions. Despite the fact that all of these countries are exporters of manufactured goods, the differences between Tables 3 and 4 are not easily summarized. In Table 4, for example, France's terms of trade and those of the US are more strongly driven by country effects (compared with Table 3). For Japan and the UK, by contrast, the goods price components are more important in the Table 4 specification. The US and France have similar decompositions in each of Tables 3 and 4 , due to the fact that the export and import shares are similar across these two countries (see Table 1) and there is similar volatility in goods and country prices (Table 2). Germany and Italy are another pair of countries for which shares and relative price volatilities are quite similar, leading to similar findings within each of Tables 3 and 4 . The results for Canada do not change much between Table 3 and Table 4 because of the similarity between Canada's export shares and import shares. Finally, the results for Japan are very different between Tables 3 and 4 primarily because export shares in Japan are so different from import shares. 
Figure 1 contains distributional information on the importance of the goods price component for each of the three groups of countries-exporters of commodities, fuels, and manufactures. In this figure, each country is treated as one observation; for purposes of comparison, results for the two decompositions (Tables 3 and 4, corresponding to equations (10) and (13)) are shown on the same graphs.

The left-hand panels of this figure contain histograms, where the horizontal axis contains deciles corresponding to the percentage of terms of trade variance due to goods price effects, and the vertical axis shows the fraction of each group that falls within a particular decile. These histograms tell us how important the goods-price effect is for a particular group of countries, and also tell us whether there is much dispersion with each group in the importance of the goods-price effect. The righthand panels contain cumulative histograms computed from the histogram for the country group shown immediately to its left.

Beginning with commodity exporters (the top panels of Figure 1), we see a roughly uniform distribution in terms of the fraction of terms of trade variance explained by goods prices. This is evident in the histogram on the left; it is also evident in the gentle slope of the cumulative histogram shown on the right. For some commodity exporters, goods prices explain little of the overall terms of trade variance; for others, goods prices explain a great deal. The decomposition reported in Table 3, represented in this figure by the hatched bars, results in a smaller contribution from the goodsprice component than the decomposition from Table 4 (the solid bars). This is easier to see in the cumulative histogram, where the line for Table 3 lies to the left of that for Table 4.

The middle panel is for fuel exporters-we saw in Tables 3 and 4 that the goods price component is very important for fuel exporters, taken as a group. The histogram shows that the distribution is fairly concentrated as well: the goods price component explains a very large percentage of the overall terms of trade for most of the countries in this group. The concentration in the distribution is also evident in the shape of the cumulative histogram, which starts out fairly flat and then rises dramatically for higher deciles of the goods price component.

The bottom panel is for exporters of manufactured goods. For these countries, the distribution is more diffuse than for fuel exporters, but not as diffuse as commodity exporters. For about $80 \%$ of the manufactured-goods exporters, the goods price explains less than $50 \%$ of the variation in the terms of trade-this is easily seen on the 
cumulative histogram. Yet this figure shows that there is a great deal of variation within this group in the exact fraction of terms of trade volatility stemming from goods price effects.

\section{Conclusion}

This paper asks about the sources of terms of trade volatility, specifically addressing the relative importance of goods-price effects vs. country-price effects. We showed that there is not a unique decomposition of this form, and presented results for two alternative decompositions. Although we found that there was substantial variation across countries in the contributions of goods prices vs. country prices, some broad findings did emerge. For fuel exporters, most of the terms of trade variation stems from goods-price effects. This accords well with one would have expected, a priori. For commodity exporters, there was great dispersion in the importance of goods price effects vs. country price effects, and no overall generalization was possible. Exporters of manufactured goods face terms of trade variation that appears to be about equally due to goods-price effects and country-price effects.

It is worth considering further the economics behind our decomposition. Certainly variation in relative goods prices is easy enough to understand-but what do we mean when we say that there is variation in a country price component? The price of, say, manufactures exports relative to the price of manufactures imports may fluctuate because of failure of the law of one price. On the other hand, this "country price" may fluctuate simply because the country imports and exports different baskets of manufactured goods. Because we are dealing with goods at a fairly high level of aggregation, it is reasonably likely that export and import baskets differ within each of our three categories of goods. To the extent that this is the case, we will attribute too much to "country prices" and too little to "goods prices."

Although this paper is primarily interested in exploring the sources of terms of trade volatility in an accounting sense, our results nevertheless have implications for theory and empirical work in international economics. This sub-section briefly summarizes the main issues.

Many papers that develop quantitative models of open economy business cycles have been concerned about the inability of the model to match the terms of trade volatility observed in the data: see, for example, Backus, Kehoe and Kydland (1994, 
1995) and Stockman and Tesar (1995). Most of these early models had a small number of production sectors, and the goods produced were durable manufactured goods-there was no role for energy (fuels) or primary commodities either in production or trade. These early models produced very little terms of trade volatility: Backus, Kehoe, and Kydland explain about $2 \%$ of overall terms of trade variance, while Stockman and Tesar explain about 14\%. Our analysis has shown that the terms of trade for manufactured-goods alone is only about two-thirds as volatile than the overall terms of trade. Thus models that abstract from commodity trade and fuel trade should be trying to match the manufactured-goods terms of trade, which is only about two-thirds as volatile as the overall terms of trade. As a fraction of the variance in manufactured-goods terms of trade, these models explain only $3 \%$ (Backus, et al.) and 21\% (Stockman and Tesar).

For developed countries, we found that the goods-price component explains about half of the terms of trade variance, although there are important differences across countries within this group. International macroeconomic models of trade, even between developed countries, should therefore build in an important role for production and trade of commodities and fuels, as well as manufactured goods. Several recent papers have attempted to do just that. Kim and Loungani (1992) build a model with energy as a productive input and exogenous energy price shocks. They show that this modification reduces somewhat the baseline model's reliance on exogenous technology shocks. Two papers that specifically attempt to replicate terms of trade volatility are Backus and Crucini (1998) and Kouparitsas (1996). Backus and Crucini (1998) model trade between developed and developing countries, incorporating a role for fuels as a traded input to production. Their model predicts that the variance in the terms of trade $40 \%-50 \%$ as large as that in the data, which is a marked improvement over the earlier literature. Kouparitsas (1996) also models trade between developed and developing countries, and builds in an important role for traded intermediate goods as well as primary products (fuels) and manufactured goods. The terms of trade variance generated by his model is $95 \%$ of that found in the data.

Finally, we found that there is an important role for country price effects in explaining variation in the terms of trade. Country prices were most important for exporters of manufactured goods and commodities, and were less important for fuel exporters. The importance of the country price components may be due to the level of aggregation used in our study. However, the importance of country prices is 
especially large for manufactured goods, and suggests to us that international macro models should build in a reason for different import and export prices of manufactured goods. Some possible reasons include product differentiation, pricing to market, or barriers to trade. This is an important avenue for future research. 


\section{References}

[1] Engel, C., 1993, Real exchange rates and relative prices: An empirical investigation, Journal of Monetary Economics 32, 35-50.

[2] ____, 1999, Accounting for US real exchange rate changes, Journal of Political Economy 107, 507-538.

[3] Engel, C., and J.H. Rogers, 1996, How wide is the border?, American Economic Review 86, 1112-25.

[4] Backus, D.K., and M.J. Crucini, 1998, Oil prices and the terms of trade, National Bureau of Economic Research Working paper 6697.

[5] Backus, D.K., P.J. Kehoe and F.E. Kydland, 1994, Dynamics of the trade balance and the terms of trade: The J-curve?, American Economic Review 84, 84-103.

[6] ____, 1995, International business cycles: Theory and evidence, in: T.F. Cooley ed., Frontiers of business cycle research (Princeton University Press, Princeton, NJ).

[7] Goldberg, P.K., and M.M. Knetter, 1997, Goods prices and exchange rates: What have we learned?, Journal of Economic Literature 35, 1243-72.

[8] Hodrick, R.J., and E.C. Prescott, 1997, Post-war U.S. business cycles: An empirical investigation, Journal of Money Credit and Banking 29, 1-16.

[9] Kim, I., and P. Loungani, 1992, The role of energy in real business cycle models, Journal of Monetary Economics 29, 173-189.

[10] Knetter, M.M., 1993, International comparisons of price-to-market behavior, American Economic Review 83, 473-86.

[11] Kouparitsas, M.A., 1996, North-South business cycles, Federal Reserve Bank of Chicago Working Paper 96-9, July 1996.

[12] Michaely, M., 1984, Trade, income levels, and dependence (North-Holland, Amsterdam). 
[13] Rogers, J.H., and M. Jenkins, 1995, Haircuts or hysteresis? Sources of movements in real exchange rates, Journal of International Economics 38, 339-360.

[14] Stockman, A.C., and L.L. Tesar, 1995, Tastes and technology in a two-country model of the business cycle: Explaining international comovements, American Economic Review 85, 168-185

[15] World Bank, 1991, World tables and STARS retrieval system version 2.00 (World Bank: Washington, D.C.). 
Table 1

\begin{tabular}{|c|c|c|c|c|c|c|c|c|c|c|}
\hline \multirow[b]{3}{*}{ Country/Region } & \multirow{3}{*}{$\begin{array}{l}\text { Terms of } \\
\text { trade } \\
\text { volatility }\end{array}$} & \multicolumn{6}{|c|}{ Terms of Trade Volatility and Trade Structure } & \multirow{2}{*}{\multicolumn{3}{|c|}{ Net export shares }} \\
\hline & & \multicolumn{3}{|c|}{ Export shares } & \multicolumn{3}{|c|}{ Import shares } & & & \\
\hline & & Commod. & Fuels & Manuf. & Commod. & Fuels & Manuf. & Commod. & Fuels & Manuf. \\
\hline \multicolumn{11}{|l|}{ Developing } \\
\hline Fuel Exporters (15) & 31.84 & 0.08 & 0.86 & 0.06 & 0.18 & 0.03 & 0.78 & -0.10 & 0.82 & -0.72 \\
\hline Manufactures Exporters (4) & 7.11 & 0.10 & 0.01 & 0.89 & 0.24 & 0.11 & 0.65 & -0.14 & -0.10 & 0.23 \\
\hline Total (79) & 18.85 & 0.32 & 0.38 & 0.29 & 0.19 & 0.10 & 0.71 & 0.14 & 0.28 & -0.42 \\
\hline Commodity Exporters (8) & 8.61 & 0.43 & 0.11 & 0.46 & 0.16 & 0.12 & 0.72 & 0.27 & 0.00 & -0.26 \\
\hline Fuel Exporters (1) & 7.53 & 0.27 & 0.28 & 0.45 & 0.15 & 0.10 & 0.75 & 0.11 & 0.18 & -0.29 \\
\hline Manufactures Exporters (12) & 9.23 & 0.14 & 0.03 & 0.82 & 0.26 & 0.21 & 0.54 & -0.12 & -0.17 & 0.29 \\
\hline Total (21) & 8.89 & 0.19 & 0.05 & 0.75 & 0.24 & 0.19 & 0.58 & -0.04 & -0.13 & 0.18 \\
\hline \multicolumn{11}{|l|}{ World } \\
\hline \multicolumn{11}{|l|}{ Major Industrial Countries } \\
\hline Canada & 9.26 & 0.35 & 0.12 & 0.53 & 0.13 & 0.08 & 0.79 & 0.22 & 0.04 & -0.26 \\
\hline France & 8.01 & 0.22 & 0.03 & 0.75 & 0.22 & 0.19 & 0.59 & 0.01 & -0.16 & 0.15 \\
\hline Germany & 8.66 & 0.09 & 0.03 & 0.88 & 0.26 & 0.16 & 0.58 & -0.17 & -0.13 & 0.30 \\
\hline Italy & 9.98 & 0.10 & 0.05 & 0.84 & 0.31 & 0.22 & 0.47 & -0.21 & -0.17 & 0.38 \\
\hline Japan & 14.54 & 0.04 & 0.00 & 0.96 & 0.38 & 0.37 & 0.25 & -0.35 & -0.36 & 0.71 \\
\hline United Kingdom & 6.82 & 0.13 & 0.10 & 0.77 & 0.28 & 0.12 & 0.59 & -0.15 & -0.02 & 0.18 \\
\hline United States & 7.84 & 0.25 & 0.04 & 0.71 & 0.18 & 0.19 & 0.63 & 0.07 & -0.16 & 0.08 \\
\hline
\end{tabular}

Source: Authors' calculations based on data from World Bank (1991).

Notes: 1. Entries refer to export-weighted average of the group, except in the case of major industrial countries where the reported statistics are for individual countries. 2. Volatility is measured by the standard deviation of the annual growth rate. 
Table 2

\begin{tabular}{|c|c|c|c|c|c|c|c|c|c|c|}
\hline \multirow[b]{3}{*}{ Country/Region } & \multirow{3}{*}{$\begin{array}{c}\text { Terms of } \\
\text { trade } \\
\left(\mathbf{p}^{\mathbf{x}}-\mathbf{p}^{\mathbf{m}}\right)\end{array}$} & \multicolumn{6}{|c|}{$\begin{array}{r}\text { Volatility of relative prices } \\
\text { Goods prices }\end{array}$} & \multirow{2}{*}{\multicolumn{3}{|c|}{ Country prices }} \\
\hline & & \multicolumn{3}{|c|}{ Export prices } & \multicolumn{3}{|c|}{ Import prices } & & & \\
\hline & & $\left(p_{c}{ }^{x}-p_{m}{ }^{x}\right)$ & $\left(p_{f}^{x}-p_{m}{ }^{x}\right)$ & $\left(p_{c}{ }^{x}-p_{f}^{x}\right)$ & $\left(p_{c}{ }^{m}-p_{m}{ }^{m}\right)$ & $\left(p_{f}{ }^{m}-p_{m}{ }^{m}\right)$ & $\left(p_{c}{ }^{m}-p_{f}{ }^{m}\right)$ & $\left(p_{c}{ }^{x}-p_{c}{ }^{m}\right)$ & $\left(p_{f}^{x}-p_{f}^{m}\right)$ & $\left(p_{m}{ }^{x}-p_{m}{ }^{m}\right)$ \\
\hline Developing & & & & & & & & & & \\
\hline Fuel Exporters (15) & 31.84 & 17.49 & 35.82 & 37.20 & 10.86 & 30.15 & 29.39 & 9.16 & 9.33 & 12.94 \\
\hline Manufactures Exporters (4) & 7.11 & 8.89 & 35.67 & 37.04 & 10.41 & 30.49 & 30.29 & 5.63 & 8.28 & 8.52 \\
\hline Total (79) & 18.85 & 15.14 & 35.98 & 37.32 & 10.89 & 29.87 & 29.93 & 8.95 & 8.86 & 10.79 \\
\hline Commodity Exporters (8) & 8.61 & 11.85 & 28.61 & 25.44 & 11.11 & 30.82 & 31.05 & 5.67 & 29.93 & 7.42 \\
\hline Fuel Exporters (1) & 7.53 & 14.74 & 32.47 & 36.98 & 11.05 & 30.97 & 30.35 & 5.94 & 10.90 & 5.71 \\
\hline Manufactures Exporters (12) & 9.23 & 12.62 & 29.56 & 25.03 & 12.18 & 29.65 & 30.63 & 4.80 & 25.28 & 6.57 \\
\hline Total (21) & 8.89 & 12.51 & 29.13 & 25.09 & 11.91 & 29.99 & 30.73 & 4.92 & 25.88 & 6.42 \\
\hline \multicolumn{11}{|l|}{ World } \\
\hline \multicolumn{11}{|l|}{ Major Industrial Countries } \\
\hline Canada & 9.26 & 12.82 & 29.04 & 27.94 & 10.24 & 30.31 & 31.63 & 5.06 & 36.39 & 6.00 \\
\hline France & 8.01 & 11.70 & 28.78 & 21.85 & 11.77 & 31.40 & 30.64 & 4.28 & 28.45 & 6.03 \\
\hline Germany & 8.66 & 11.52 & 31.11 & 24.34 & 12.40 & 31.87 & 30.79 & 2.55 & 28.54 & 5.66 \\
\hline Italy & 9.98 & 11.33 & 33.99 & 27.66 & 11.69 & 31.03 & 30.63 & 4.65 & 27.39 & 6.44 \\
\hline Japan & 14.54 & 13.50 & 33.93 & 28.18 & 14.65 & 24.67 & 30.32 & 6.81 & 27.61 & 11.33 \\
\hline United Kingdom & 6.82 & 11.54 & 36.53 & 36.58 & 11.41 & 29.58 & 30.08 & 2.35 & 7.46 & 5.11 \\
\hline United States & 7.84 & 14.85 & 17.09 & 16.11 & 11.01 & 29.45 & 31.19 & 5.57 & 25.03 & 5.04 \\
\hline
\end{tabular}

Source: Authors' calculations based on data from World Bank (1991).

Notes: 1. Entries refer to export-weighted average of the group, except in the case of major industrial countries where the reported statistics are for individual countries. 2. Volatility is measured by the standard deviation of the annual growth rate. 
Table 3

Terms of trade variance decomposition

Export shares for country prices

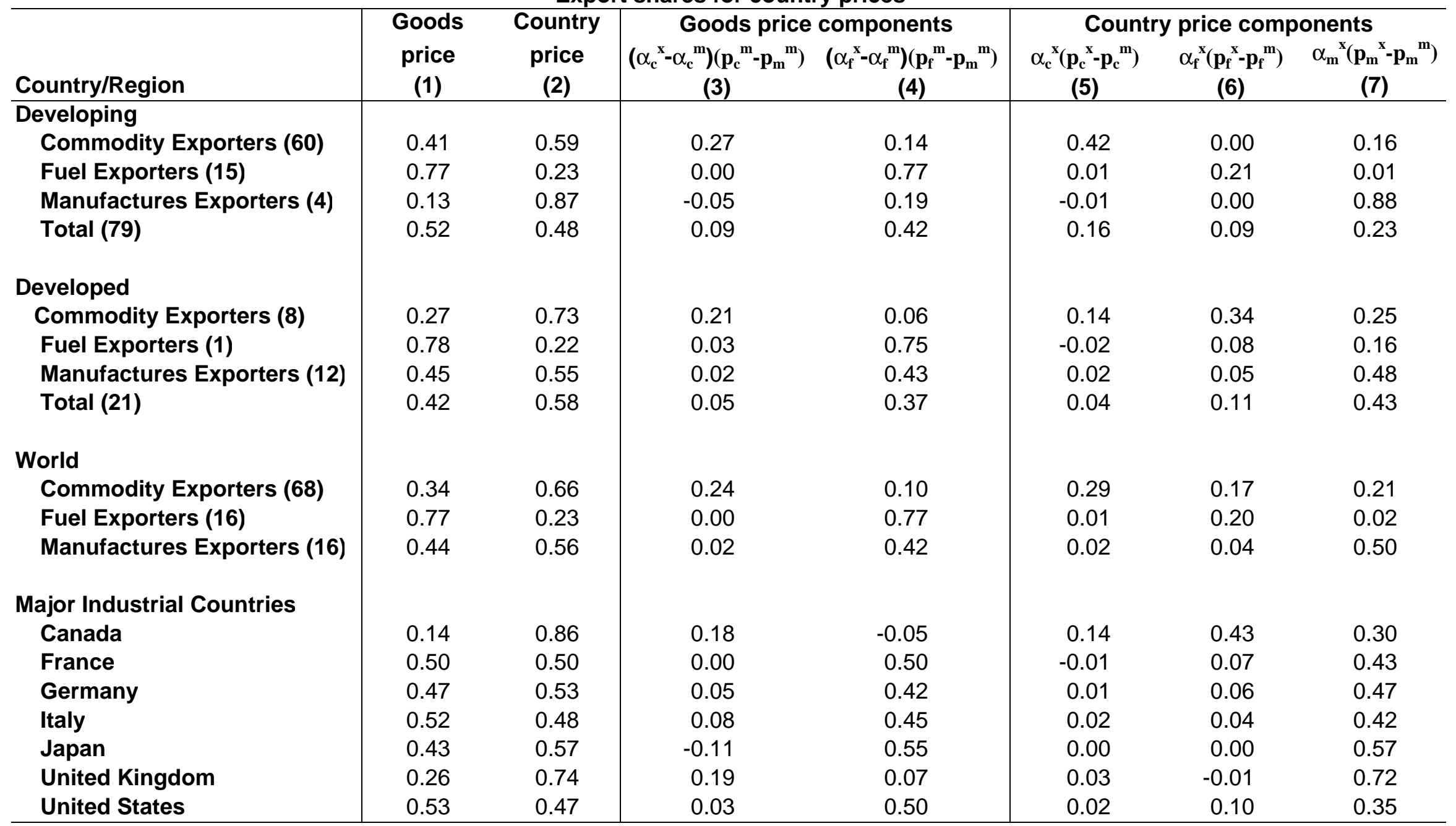

Source: Authors' calculations based on data from World Bank (1991).

Note: Entries refer to export-weighted average of the group, except in the case of major industrial countries where the reported statistics are for individual countries. 
Table 4

Terms of trade variance decomposition

Import shares for country prices

\begin{tabular}{|c|c|c|c|c|c|c|c|}
\hline \multirow[b]{2}{*}{ Country/Region } & \multirow{2}{*}{$\begin{array}{l}\text { Goods } \\
\text { price } \\
\text { (1) }\end{array}$} & \multirow{2}{*}{$\begin{array}{c}\text { Country } \\
\text { price } \\
\text { (2) }\end{array}$} & \multicolumn{2}{|c|}{ Goods price components } & \multicolumn{3}{|c|}{ Country price components } \\
\hline & & & $\begin{array}{c}\left(\alpha_{c}{ }^{x}-\alpha_{c}{ }^{m}\right)\left(p_{c}{ }^{x}-p_{m}{ }^{x}\right) \\
(3)\end{array}$ & $\begin{array}{c}\left(\alpha_{f}^{x}-\alpha_{f}^{m}\right)\left(p_{f}^{x}-p_{m}{ }^{x}\right) \\
(4)\end{array}$ & $\begin{array}{c}\alpha_{c}{ }^{m}\left(\mathbf{p}_{c}{ }^{x}-p_{c}{ }^{m}\right) \\
(5)\end{array}$ & $\begin{array}{c}\alpha_{f}^{m}\left(p_{f}^{x}-p_{f}^{m}\right) \\
(6)\end{array}$ & $\begin{array}{c}\alpha_{m}{ }^{m}\left(p_{m}{ }^{x}-p_{m}{ }^{m}\right) \\
(7)\end{array}$ \\
\hline \multicolumn{8}{|c|}{$\begin{array}{llll} & 0 \\
\end{array}$} \\
\hline Commodity Exporters (60) & 0.61 & 0.39 & 0.39 & 0.22 & 0.12 & -0.04 & 0.32 \\
\hline Fuel Exporters (15) & 0.88 & 0.12 & 0.01 & 0.87 & 0.01 & 0.01 & 0.10 \\
\hline Manufactures Exporters (4) & 0.41 & 0.59 & 0.09 & 0.32 & -0.02 & -0.05 & 0.66 \\
\hline Total (79) & 0.66 & 0.34 & 0.15 & 0.51 & 0.05 & -0.02 & 0.31 \\
\hline \multicolumn{8}{|l|}{ Developed } \\
\hline Commodity Exporters (8) & 0.14 & 0.86 & 0.10 & 0.04 & 0.04 & 0.35 & 0.46 \\
\hline Fuel Exporters (1) & 0.72 & 0.28 & -0.02 & 0.74 & -0.01 & 0.03 & 0.27 \\
\hline Manufactures Exporters (12) & 0.37 & 0.63 & 0.09 & 0.28 & 0.02 & 0.29 & 0.31 \\
\hline Total (21) & 0.32 & 0.68 & 0.09 & 0.24 & 0.03 & 0.32 & 0.33 \\
\hline \multicolumn{8}{|l|}{ World } \\
\hline Commodity Exporters (68) & 0.38 & 0.62 & 0.25 & 0.13 & 0.08 & 0.15 & 0.39 \\
\hline Fuel Exporters (16) & 0.87 & 0.13 & 0.01 & 0.86 & 0.01 & 0.01 & 0.11 \\
\hline Manufactures Exporters (16) & 0.38 & 0.62 & 0.09 & 0.28 & 0.02 & 0.27 & 0.33 \\
\hline \multicolumn{8}{|l|}{ Major Industrial Countries } \\
\hline Canada & 0.22 & 0.78 & 0.15 & 0.07 & 0.05 & 0.29 & 0.44 \\
\hline France & 0.19 & 0.81 & 0.00 & 0.19 & -0.01 & 0.48 & 0.34 \\
\hline Germany & 0.36 & 0.64 & 0.12 & 0.24 & 0.02 & 0.31 & 0.31 \\
\hline Italy & 0.56 & 0.44 & 0.15 & 0.41 & 0.05 & 0.16 & 0.23 \\
\hline Japan & 0.71 & 0.29 & 0.12 & 0.60 & -0.03 & 0.17 & 0.15 \\
\hline United Kingdom & 0.40 & 0.60 & 0.30 & 0.10 & 0.07 & -0.02 & 0.55 \\
\hline United States & 0.16 & 0.84 & -0.01 & 0.16 & 0.01 & 0.52 & 0.31 \\
\hline
\end{tabular}

Source: Authors' calculations based on data from World Bank (1991).

Note: Entries refer to export-weighted average of the group, except in the case of major industrial countries where the reported statistics are for individual countries. 
The importance of goods price effects across countries

Commodity Exporters

Histogram

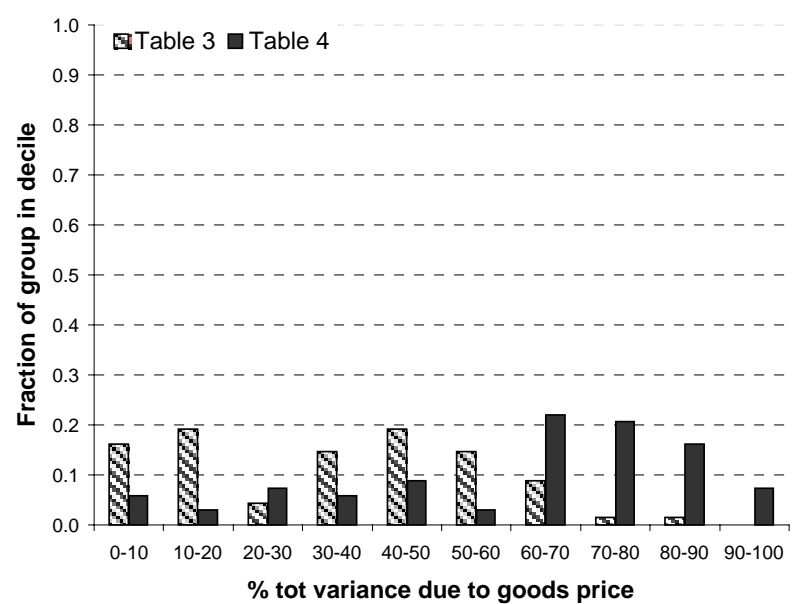

Fuel Exporters Histogram

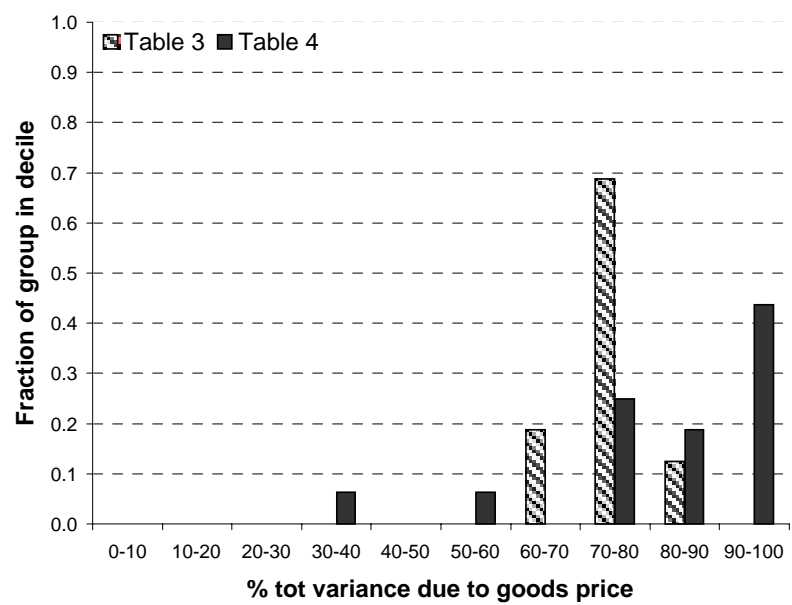

Manufactures Exporters Histogram

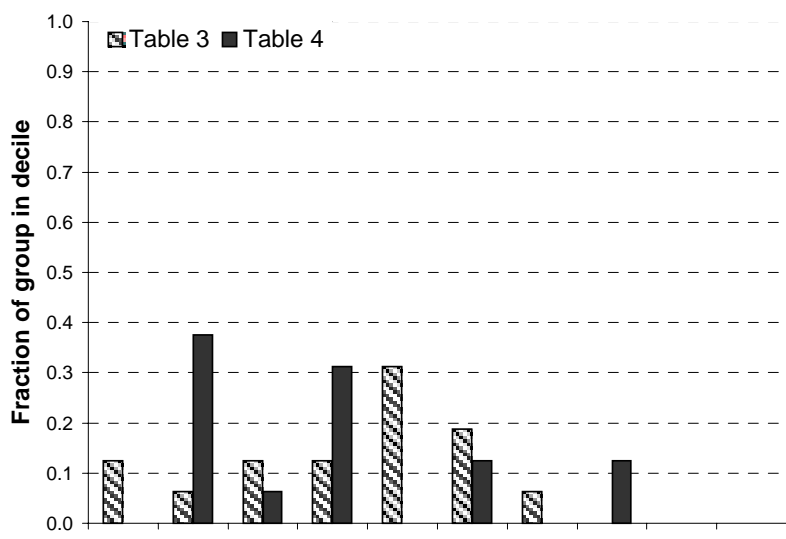

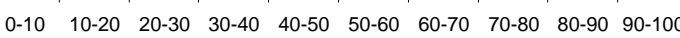
$\%$ tot variance due to goods price
Commodity Exporters

Cumulative histogram

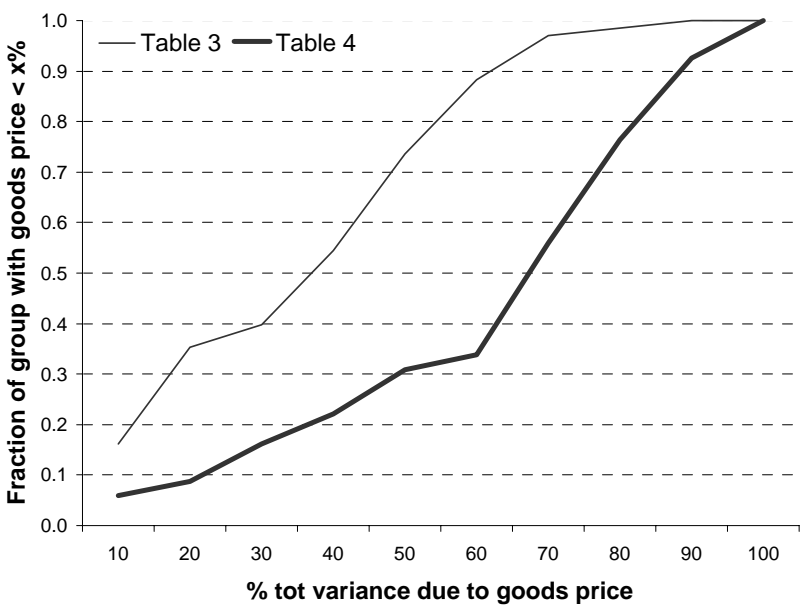

Fuel Exporters

Cumulative histogram

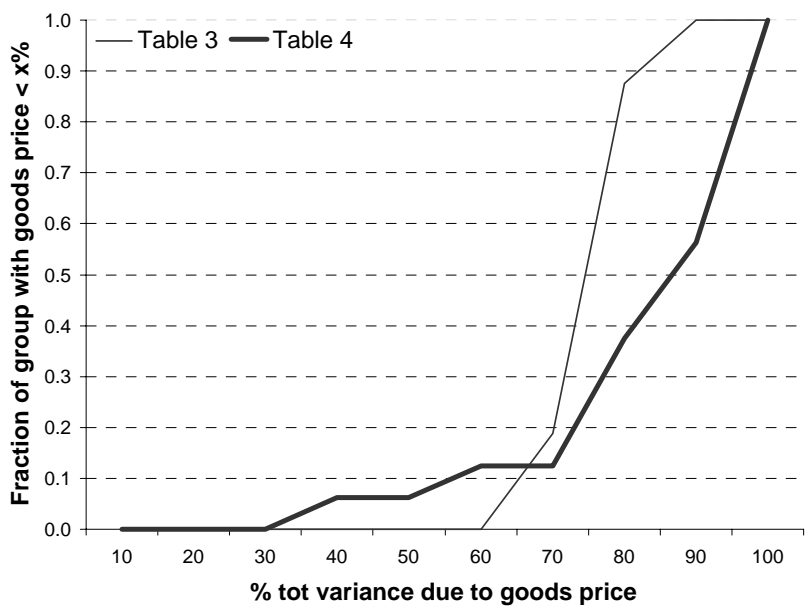

Manufactures Exporters

Cumulative histogram

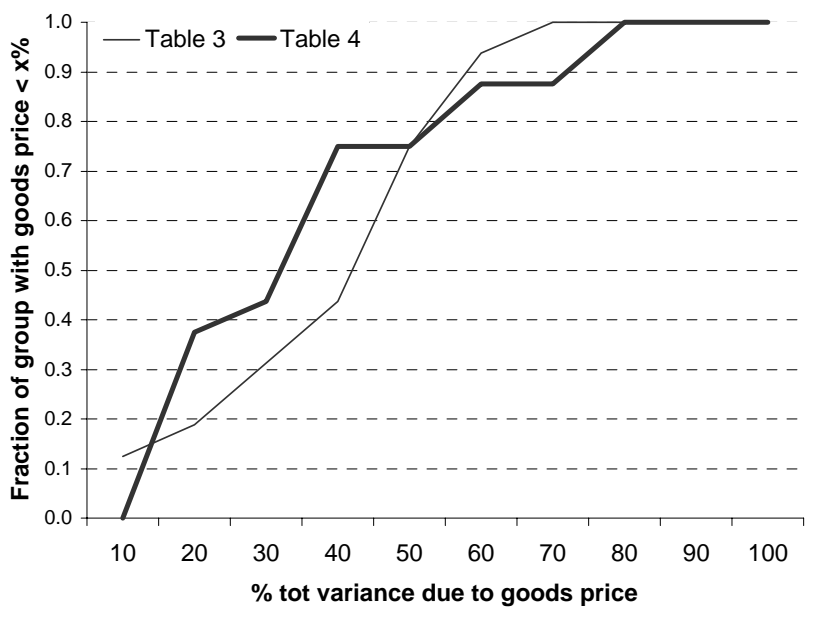




\section{Appendix A: Country List}

Hong Kong

Malta

Argentina
Barbados
Benin
Bolivia
Botswana
Brazil
Burkina Faso
Cameroon
Central African Republic
Chile
Colombia
Costa Rica
Cyprus
Dominican Republic
El Salvador
Ethiopia
Fiji
Gambia, The
Ghana
Guatemala

Algeria
Congo
Ecuador
Egypt
Gabon

\section{Developing Countries}

Manufactured Goods Exporters

Israel

Republic of Korea

\section{Commodity Exporters}

Guyana

Haiti

Honduras

India

Jamaica

Jordan

Kenya

Lesotho

Madagascar

Malawi

Malaysia

Mali

Mauritania

Mauritius

Morocco

Nepal

Nicaragua

Niger

Pakistan

Panama

\section{Fuel Exporters}

Indonesia

Kuwait

Mexico

Nigeria

Saudi Arabia
Papua New Guinea

Paraguay

Peru

Philippines

Rwanda

Senegal

Sierra Leone

Singapore

Somalia

South Africa

Sudan

Tanzania

Thailand

Togo

Turkey

Uganda

Uruguay

Zaire

Zambia

Zimbabwe

Syrian Arab Republic

Trinidad and Tobago

Tunisia

United Arab Emirates

Venezuela

\section{Developed Countries}

Austria

Finland

France

Germany

Australia

Canada

Denmark
Manufactured Goods Exporters

$$
\begin{aligned}
& \text { Italy } \\
& \text { Japan } \\
& \text { Portugal } \\
& \text { Spain }
\end{aligned}
$$

Commodity Exporters

Greece

Iceland

Ireland

Fuel Exporters
Sweden

Switzerland

United Kingdom

United States

Netherlands

New Zealand

Norway 